to $8 \mathrm{~h}$. om. I counted fifty meteors. The observer's face was north-west. The sky was clear to within ten or fifteen degrees of the horizon. The meteors were generally very small, and I noticed only four or five near the zenith that left trails behind that endured a few seconds. In one respect the meteors were remarkable : they all appeared to radiate from a point between the great square in Pegasus and the chair in Cassiopeia, so that during my two watches I saw but a single meteor that could properly be called sporadic. Bylaying down some of the tracks on a globe, I found the following rough position of the radiant point :-

$$
\mathrm{AR}=355^{\circ}, \text { Decl. }=+43^{\circ} \text {. }
$$

From this position of the radiant point I have computed the following elements of the orbit of the meteoric stream, and by the side of these have placed the corresponding number of Biela's comet :-

$$
\begin{aligned}
& \text { Meteoric Stream. } \\
& \begin{array}{ll}
\pi & =89^{\circ} 5^{\circ} \\
\Omega & =246^{\circ}
\end{array} \\
& \begin{array}{l}
\Omega \\
i=154
\end{array} \\
& \log q=\quad 9.976
\end{aligned}
$$

\begin{tabular}{lll}
\multicolumn{3}{r}{ Biela's Comet } \\
$\pi$ & $=$ & $1090^{\circ}$ \\
$\Omega$ & $=$ & $2455^{\circ}$ \\
$i$ & $=$ & 12.6 \\
$\log q$ & $=$ & 9.933
\end{tabular}

These elements are so much alike, that there can be but little doubt that the meteors are the transformed particles of Biela's comet.

ASAPH HALI

Washington, Dec. $\mathbf{I}$

ON the evening of November 27, Prof. Tingley, of Asbury University, Greencastle, Indiana, observed a remarkable shower of falling stars. The number counted in 40 minutes, from $7 \mathrm{~h}$. $15 \mathrm{~m}$. to $7 \mathrm{~h}$. $55 \mathrm{~m}$., was $\mathrm{I} 1 \mathrm{O}$. This would give $\mathrm{I} 65$ per hour for one observer, But according to Prof. Newton ( $S_{i}^{t} / j$ man's Foumal, for January I868, p. 80), the whole number visible at any station, when the sky is entirely clear, is five times the number seen by a single observer. The enumeration by Prof. Tingley accordingly indicates an actual fall of 825 per hour.

It was remarked by the writer several years since* that the last days of November were worthy of close attention as the probable date of a meteoric shower. The same period had been previously designated by Mr. R. P. Greg, as an aërolitic epoch. The observed showers of falling stars which may be referred to this stream are as follows :-

$$
\begin{array}{ccc}
\text { A.D. } 837, \text { Nov. 12, cor. to Nov. } 27 \text { for } 1850 . \\
899, & 18, & \text { Dec. } 2 \\
1850, & 29 \\
1872, & 27
\end{array}
$$

The epoch corresponds with that at which the earth crosses the orbit of Biela's comet. This body is no longer visible in its cometary form, having undergone the process of disintegrationa process which doubtless commenced at a very remote period. The fact, then, can scarcely be doubted that the meteors of this epoch are the results of this comet's gradual dissolution.

Bloomington, Ind., Nov. 28

DANIEL KIRKWOOD

THE aurora of Nov. 27-the evening of the meteoric displaywas seen by me near Liverpool. It appears to have been very partial in its manifestation, to judge by the published accounts. There was merely a hazy or diffused cloudy light, devoid both of colouring and symmetry of form. This variety of aurora I have observed on several occasions, when it appears to have attracted but few observers.

I may draw attention now to the fact of another display of aurora on Nov. ro (noticed first at about Ir.20 P.M.). This was of the usual form, ruddy, and radiating from a horizontal band of light in the north. It was followed by a week of much colder weather than had preceded it.

Liverpool, Dec. 13

\section{Samuel Barber}

As the number of meteors which I counted on the evening of Wednesday last, November 27 , varied considerably from the number in Mr. Lowe's tables (Times, November 29), I beg to offer you my observations, in case they should be of any value on account of the more southern point from which they were taken. I lay down on my back upon the flat roof of the house in which

$$
\text { * “Mẹteoric Astronomy," p. } 55 .
$$

I live, and looked up towards the zenith. The radiating point of most of the meteors seemed to be in the area between Cassiopeia and Perseus. I observed a bright one between the stars repre. senting the feet of Andromeda. It disappeared without traversing almost any visible track or angular distance, from which I drew the inference that it was near the radiating point. The number I counted was as follows :-

\begin{tabular}{rrcc}
\multicolumn{2}{c}{ Time. } & $\begin{array}{c}\text { No. in } \\
\text { h. }\end{array}$ & $\begin{array}{c}\text { Average } \\
\text { minutes. }\end{array}$ \\
6 & $34-39$ & 150 & No. per minute. \\
6 & $39-44$ & 140 & 30 \\
6 & $45-50$ & 150 & 38 \\
6 & $50-55$ & 180 & 36 \\
7 & $1-6$ & 160 & 32 \\
7 & $7-12$ & 160 & 32 \\
7 & $17-22$ & 170 & 34 \\
7 & $30-35$ & 180 & 36 \\
7 & $40-45$ & 180 & 36 \\
8 & $48-53$ & 150 & 30 \\
10 & $5-10$ & 80 & 16 \\
10 & $24-29$ & 70 & 14
\end{tabular}

Between 8 and 8.30 , a friend and I counted together about 50 per-minute.

Pau, Dec. 2

J. F. ANDERSON

The De Novo Production of Living Things

IN reply to Mr. E. Ray Lankester's inquiry in the last number of NATURE, I beg to state that the specific gravity of an infusion of turnip, prepared in the manner I have directed, was found to be 1012, whilst that of an infusion of hay was roo5.

University College, London, Dec. I6 H. Charlton Bastian

\section{The Ocean Rainfall}

ON reading the article on "The Meteorology of the Future," in NATURE, December I2, I pondered over this passage- "It is impossible to determine the rainfall over the ocean;" and it occurred to me that it is possible to do something in that line approximately. Is the Challenger supplied with raingauges ? Would it not be possible to determine in some measure the hourly amount of rainfall over the ocean, in the zones of greatest precipitation, or in those of periodical rains, without detaining the ship unduly; and would not such data be useful in solving some of the problems connected with the working out of the law of cyclones?

Another suggestion has occurred to me-that is, that raingauges might be placed in "floating lights," and the rainfall at sea thus obtained. I need not now inquire through what channel this might be effected, or what particular structure and fixing of the gauges might be necessary. I should be glad to elicit the opinion of some of the readers of NATURE as to the practica. bility and utility of such a scheme. ? S. H. MILLER

Wisbech, Dec. 14

\section{Ocean Meteorological Observations}

AN examination of the discussion of the daily range of the barometer for square No. 3, published under Fitzroy's direction in 1861 , which Mr. Symons has referred to at page 68 of this volume, shows that the results there arrived at can only be considered to be good as corrections for hourly observations of the barometer on the mean of the year. As regards the months, the results are, on account of the fewness of the observations on which they are based, too imperfect as indications of the true range to be available in correcting the averages on the large January chart issued by the Meteorological Committee. Since, moreover, the barometric range for January differs from that for the year, the hourly corrections for range on the mean of the year should not be applied to the January observations printed on the large chart.

Again, the prevalence in January of the south-easterly trades in the southern portion of the square, the prevalence of the north-easterly trades in the northern portion, and variable winds between, and the nnequally clouded state of the sky which re: sults therefrom, render it certain that range corrections must 